\title{
Borrelia burgdorferi - emergentna spiroheta u Primorsko-goranskoj županiji
}

\section{Borrelia burgdorferi - emergent spirochete in Primorsko-goranska County}

\author{
Barbara Kancijan ${ }^{1 *}$, Ivana Gobin², Dolores Peruč²,3
}

\begin{abstract}
Sažetak. Cilj rada: Retrospektivno istražiti pojavnost lajmske borelioze (LB) u Primorskogoranskoj županiji (PGŽ) u periodu od 1. siječnja 2018. do 31. prosinca 2019. Materijali $i$ metode: Retrospektivna analiza rezultata serodijagnostičkih metoda pretrage 1843 uzorka krvnog seruma pacijenata s epidemiološkim podatkom o ugrizu krpelja. Dobiveni rezultati uspoređeni su s podatcima HZJZ-a o prijavljenim slučajevima LB-a na području Republike Hrvatske (RH) i PGŽ-a. Rezultati: Od 1050 uzoraka pretraženih tijekom 2018. godine na prisustvo specifičnih protutijela, $34,1 \%$ imalo je pozitivna IgM protutijela na $B$. burgdorferi, dok su u uzorcima iz 2019. godine specifična protutijela detektirana u $26,1 \%$ od 793 uzorka. Porast broja pozitivnih uzoraka uočen je u razdoblju od svibnja do rujna. U 2018. godini najveći je broj uzoraka s pozitivnim IgM protutijelima bio u lipnju (19,83\%), a 2019. godine u srpnju (18,35\%). Najmanji broj pozitivnih uzoraka u obje promatrane godine zabilježen je u siječnju i prosincu. U razdoblju od 2009. do 2019. godine HZJZ je prijavio u RH $510 \pm 115,71$ oboljelih godišnje. U 2019. godini broj prijavljenih slučajeva u PGŽ-u iznosio je $42,3 \%$ od ukupnog broja slučajeva prijavljenih u RH. Zaključci: Velik broj oboljelih od LB-a u RH i PGŽ-u predstavlja sve veći javnozdravstveni problem. Ova zoonoza koja se prenosi krpeljima iz roda Ixodes pokazuje sezonski karakter, no zbog promjena klimatskih uvjeta, prvenstveno blažih zima, neophodna su istraživanja rasprostranjenosti krpelja u prirodi i preventivne mjere od infekcije.
\end{abstract}

Ključne riječi: Borrelia burgdorferi; Ixodes; Lyme borelioza; serološka dijagnostika

\begin{abstract}
Objective: To investigate retrospectively the incidence of Lyme boreliosis (LB) in the Primorsko Goranska Counti (PGC) in the period from 1 January 2018 to 31 December 2019. Materials and Methods: A retrospective analysis of the results of serodiagnostic methods of examination of 1843 blood serum samples of patients with epidemiological data on tick bites. The obtained results were compared with the data of the Croatian Institute for Public Health on reported cases of LB in the territory of the Republic of Croatia (RC) and PGC. Results: Of the 1,050 blood serum samples screened during 2018 for the presence of specific antibodies $34.1 \%$ had positive IgM antibodies to B. burgdorferi while in 2019 samples, specific antibodies were detected in $26.1 \%$ of the 793 samples. An increase in the number of positive samples was observed in the period from May to September. In 2018, the largest number of samples with positive IgM antibodies was in June (19.83\%), and in 2019 in July (18.35\%). The lowest number of positive samples in both observed years was recorded in January and December. In the period from 2009 to 2019 Croatian Institute for Public Health reported in the RC number of $510 \pm 115.71$ patients per year. In 2019, the number of reported cases in PGC amounted to $42.3 \%$ of the total number of cases reported in RC. Conclusions: A large number of patients with $\mathrm{LB}$ in the RC, as well in PGC, is a growing public health problem. This zoonosis transmitted by ticks of the genus Ixodes shows a seasonal character, but due to changes in climatic conditions, primarily milder winters, it is necessary to research the distribution of ticks in nature and implement preventive measures against infection.
\end{abstract}

Key words: Borrelia burgdorferi; Ixodes; Lyme borreliosis; serology
${ }^{1}$ Sveučilište u Rijeci, Medicinski fakultet, Rijeka, Hrvatska

${ }^{2}$ Zavod za mikrobiologiju i parazitologiju, Sveučilište u Rijeci, Medicinski fakultet, Rijeka, Hrvatska

${ }^{3}$ Mikrobiološki odjel, Nastavni zavod za javno zdravstvo Primorsko-goranske županije, Rijeka, Hrvatska

*Dopisni autor:

Barbara Kancijan, univ. bacc. sanit. ing. Sveučilište u Rijeci, Medicinski fakultet Braće Branchetta 20, 51000 Rijeka, Hrvatska E-mail: barbara.kancijan@gmail.com

http://hrcak.srce.hr/medicina 


\section{UVOD}

Borrelia burgdorferi (B. burgdorferi) spiralna je bakterija koja uzrokuje lajmsku bolest (Lyme boreliozu). Bolest je dobila ime po gradu Lymeu u sjevernoameričkoj državi Connecticut u kojem je prvi put opisana 1975 . godine ${ }^{1}$. Lajmska borelioza je zoonoza koju prenose krpelji roda Ixodes, a na području Europe prvenstveno vrsta Ixodes ricunus (šumski ili šikarni krpelj)². Životni ciklus krpelja ima četiri stadija: jaje, ličinka, nimfa i adultni oblik (slika 1). lako se ličinka i nimfa hrane krvlju, ubode u ljudi najčešće izaziva odrasla jedinka ${ }^{1,3,4}$.

Lajmska borelioza je zoonoza koju na području Europe prenose krpelji roda Ixodes ricunus. Pokazuje sezonski karakter jer ovisi o aktivnosti krpelja i intenzitetu boravka ljudi u prirodi. Preventivne mjere koje propisuje HZJZ ključne su u prevenciji ove bolesti.
Borelije su nešto većeg promjera od drugih patogenih spiroheta (od 0,2 do 0,5 $\mu \mathrm{m}$ ) te su vidljive pod mikroskopom ako se boje po Gramu, Giemsi ili Wrightu. Nutritivno su izrazito zahtjevne pa izolacija kultivacijom nije rutinska dijagnostička metoda $^{1}$. Bakterija B. burgdorferi (B. burgdorferi sensu stricto) najviše je rasprostranjena na području Europe i Sjeverne Amerike, dok su u Europi prisutne još dvije patogene vrste iz $B$. burgdorferi sensu lato kompleksa: Borrelia afzelii i Borrelia garinii ${ }^{2,5}$.

Lajmska se borelioza pojavljuje u nekoliko stadija. Prvi rani lokalizirani stadij započinje tri do 32 dana nakon ugriza krpelja promjenom na mjestu ugriza koja se naziva erythema migrans (slika 2). Eritem se širi, blijedi u sredini i migrira u druge dijelove kože. U prvom se stadiju mogu razviti opći simptomi infekcije koje karakterizira vrućica i opće loše osjećanje. Eritem spontano nestaje, no nakon nekoliko dana ili tjedana može doći do pojave drugog diseminiranog stadija koji karakterizi-
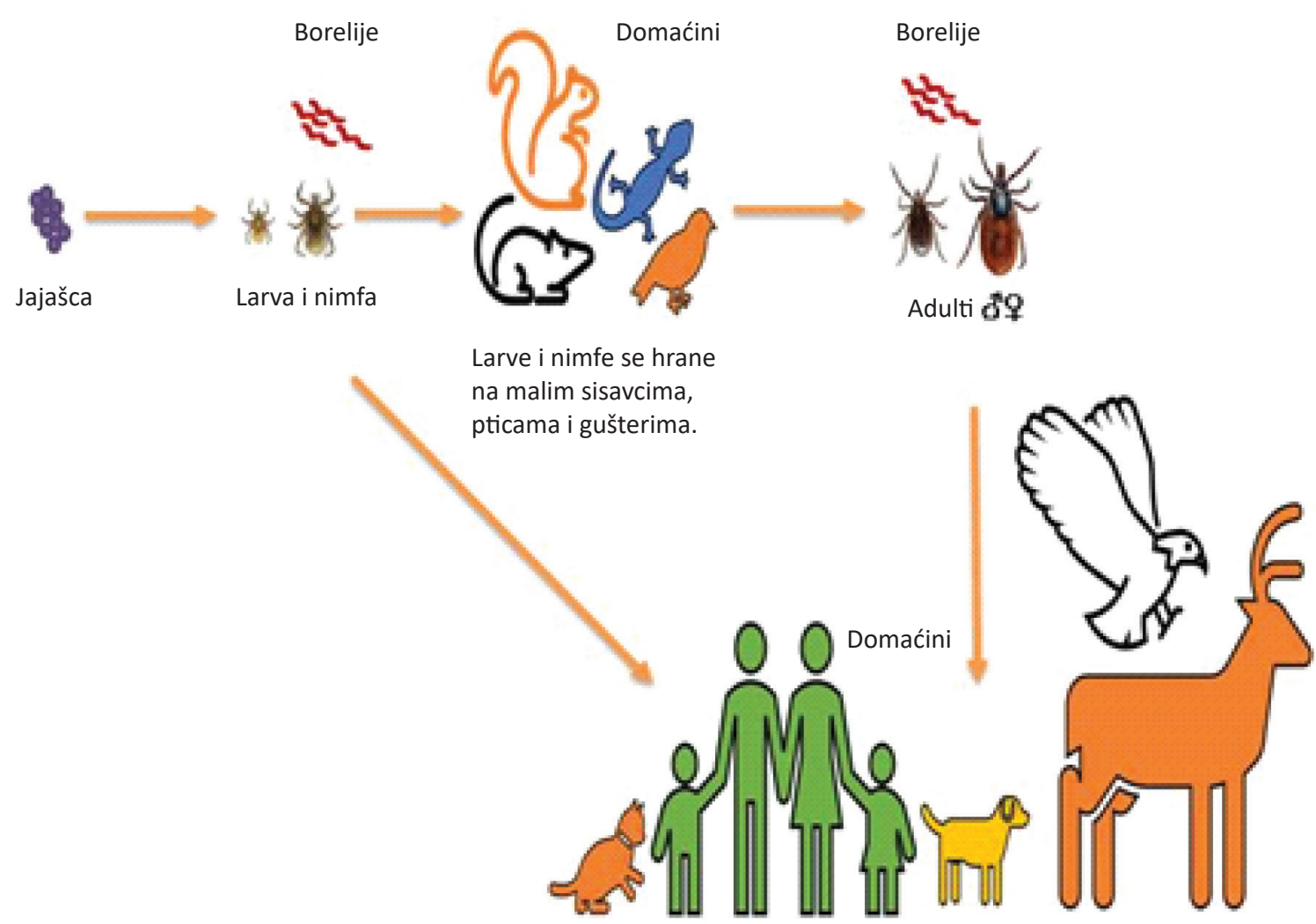

Nimfe i adulti se hrane na malim i srednjim životinjama, ali i na ljudima.

Slika 1. Životni ciklus krpelji roda Ixodes 


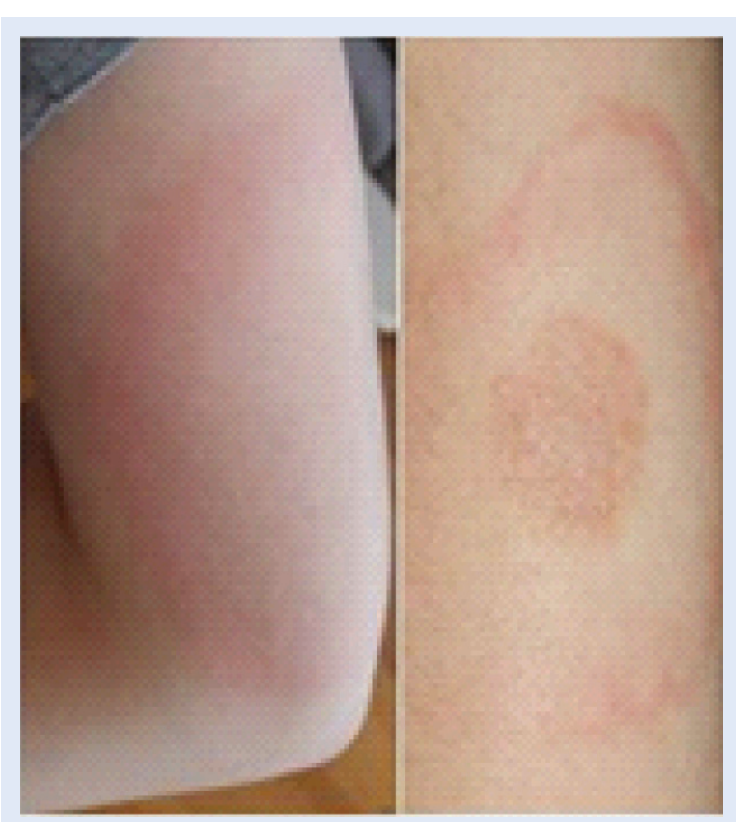

Slika 2. Erythema migrans

ra pojava karakterističnih simptoma na koži, živčanom, srčanom i mišićno-koštanom sustavu ${ }^{5}$. Treći je stadij kasna manifestacija lajmske borelioze s brojnim kožnim, koštano-zglobnim, neurološkim i kardijalnim oštećenjima. Neuroboreliozu uglavnom uzrokuje vrsta $B$. garinii, vrsta $B$. afzelii povezuje se $s$ kasnim kožnim manifestacijama (acrodermatitis chronica atrophicans), dok je artritis manifestacija infekcije $s$. burgdorferi sensu stricto. Erythema migrans mogu izazvati sve tri patogene vrste borelija ${ }^{2,4,5}$.

Dijagnoza bolesti u ranom stadiju prvenstveno se postavlja klinički nakon pozitivne epidemiološke anamneze. Mikrobiološka dijagnoza temelji se na serološkim pretragama od kojih se u praksi obično rabe imunofluorescencija, enzimni imunofluorescentni test (engl. Enzyme Linked Fluorescent Assay; ELFA), imunoenzimni test (engl. EnzymeLinked Immuno Assay; ELISA) i imunoblot (engl. Western Blot; WB) te molekularna pretraga polimerazna lančana reakcija (engl. Polymerase Chain Reaction; PCR) ${ }^{4,6}$. Serološki su testovi najvažnija metoda u dijagnostici kasnijih faza lajmske bole$s t^{1,5,6}$. Serodijagnostika borelioza provodi se u dva koraka. Inicijalno se učini test otkrivanja (ELISA ili ELFA), nakon kojeg u slučaju pozitivnog nalaza slijedi potvrda testom imunoblot (WB). Ovim se testovima otkrivaju specifična IgM i IgG protutijela na borelije reakcijom $s$ antigenima na čvrstom nosaču. Dodatkom sekundarnih, antihumanih protutijela reakcija se vizualizira pa se može odrediti količina protutijela na osnovi promjene boje otopine (ELISA ili ELFA), a u WB-u definirati prisustvo protutijela na određeni antigen pojavom ljubičaste boje na nitroceluloznoj trakici na mjestu gdje je došlo do vezanja antigena i protutijela. Specifična IgM protutijela javljaju se između 2. i 4. tjedna i dosežu maksimum od 3. do 6. tjedna nakon infekcije. Međutim, za razliku od većine drugih infekcija, specifična IgM protutijela mogu dugo biti prisutna u visokoj razini, osobito tijekom kasnih manifestacija lajmske borelioze. Nakon 6. do 8. tjedna infekcije javljaju se specifična IgG protutijela koja mogu perzistirati u visokom titru dugo nakon infekcije unatoč primijenjenoj antibiotskoj terapiji. Rana primjena antibiotske terapije može suprimirati humoralni imunološki odgovor pa kod tih pacijenata ne detektiramo specifična IgM i IgG protutijela ${ }^{5}$.

Važnu ulogu u prevenciji borelioze imaju sljedeće smjernice Hrvatskog zavoda za javno zdravstvo (HZJZ): nošenje prikladne odjeće i obuće, izbjegavanje odjeće tamnih boja i materijala poput vune i flanela, hodanje obilježenim stazama, upotreba repelenata, pregled cijelog tijela nakon povratka iz prirode, tuširanje nakon povratka iz prirode. Najviše su izloženi šumski radnici i osobe koje često borave u prirodi pa je pregled tijela nakon boravka u prirodi neophodan? ${ }^{7}$. Bolest pokazuje sezonski karakter te ovisi o aktivnosti krpelja, njihovoj dijapauzi, aktivnosti izletnika i drugim čimbenicima ${ }^{4}$.

Cilj rada bio je retrospektivno istražiti pojavnost lajmske borelioze u PGŽ-u u periodu od 1. siječnja 2018. do 31. prosinca 2019. na osnovi rezultata serodijagnostičkih metoda pretrage 1843 uzorka krvnog seruma pacijenata s epidemiološkim podatkom o ugrizu krpelja. Zatim su dobiveni rezultati uspoređeni s podatcima HZJZ-a o prijavljenim slučajevima lajmske bolesti na području Republike Hrvatske (RH) i PGŽ-a koji su objavljeni u Hrvatskome zdravstveno-statističkom ljetopisu $(\mathrm{HZSLJ})^{8}$.

\section{MATERIJALI I METODE}

Ukupno su pretražena 1843 uzorka krvnog seruma pacijenata na IgM i IgG protutijela protiv 


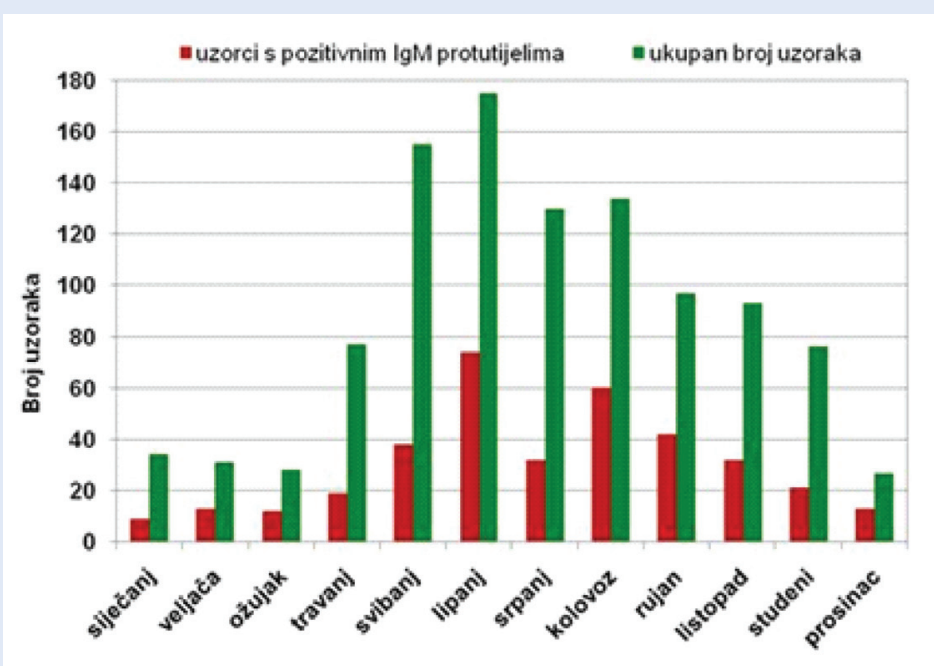

Slika 3. Prikaz rezultata imunofluorescentnog (ELFA) i potvrdnog western blot (WB) testa krvnog seruma pacijenata suspektnih na lajmsku boreliozu u Primorsko-goranskoj županiji po mjesecima 2018. godine

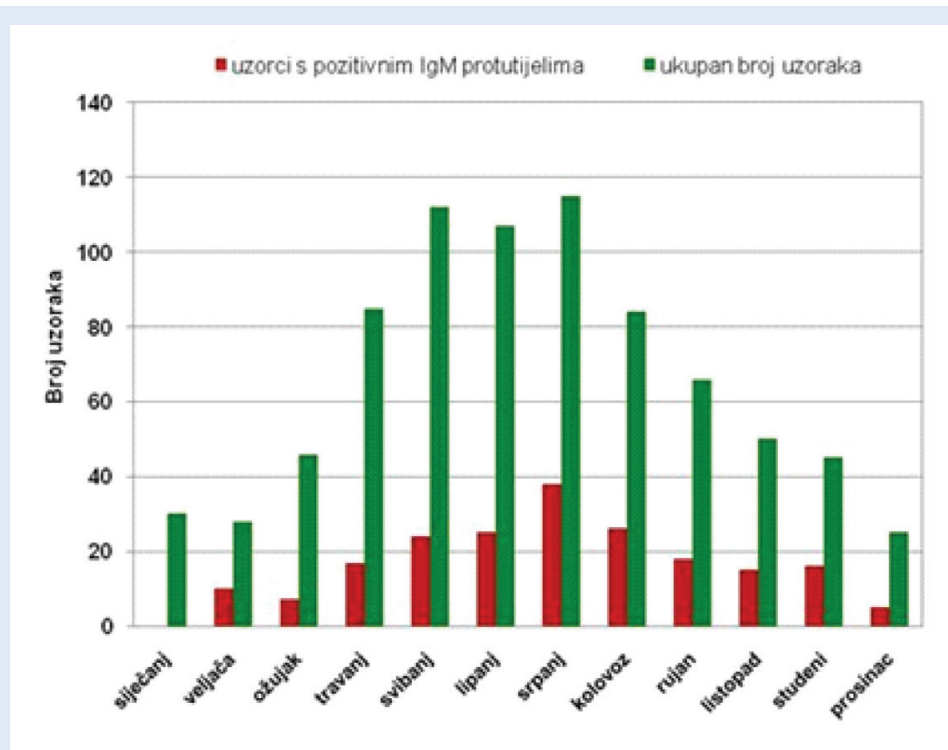

Slika 4. Prikaz rezultata imunofluorescentnog (ELFA) i potvrdnog western blot (WB) testa krvnog seruma pacijenata suspektnih na lajmsku boreliozu u Primorsko-goranskoj županiji po mjesecima 2019. godine

Broj oboljelih od lajamske borelioze u Hrvatskoj od 2009. do 2019. godine varira i prosječno iznosi oko $510 \pm 115,71$ prijava godišnje. U Primorsko-goranskoj županiji veća je pojavnost oboljelih na područja grada Rijeke i gradova Liburnije u odnosu na Gorski kotar, Vinodol i otoke u Kvarnerskom zaljevu.
Borrelia burgdorferi sensu lato koji su imali epidemiološki podatak o ugrizu krpelja, a zaprimljeni su na Mikrobiološki odjel Nastavnog zavoda za javno zdravstvo Primorsko-goranske županije (NZJZ PGŽ-a). U 2018. godini je prikupljeno 1050 uzoraka, dok su 2019. godine prikupljena 793 uzorka.

Inicijalno je proveden kvalitativni enzimni imunofluorescentni test (engl. Enzyme Linked Fluorescent Assay; ELFA) VIDAS ${ }^{\circ}$ Lyme IgM i VIDAS ${ }^{\circ}$ Lyme IgG, Biomerieux, Marcy-l'Étoile, Francuska, na uređaju VIDAS, Biomerieux, Marcy-l'Étoile, Francuska. Pozitivni nalazi IgM i/ili IgG protutijela potvrđeni su Euroimmun Anti-Borrelia EUROLINE-WB IgM i Euroimmun Anti-Borrelia EUROLINE-WB IgG, Euroimmun, Lubeck, Njemačka te evaluirani vizualno i uz pomoć automatiziranog softvera EUROLineScan, Euroimmun, Lubeck, Njemačka.

\section{REZULTATI}

Tijekom 2018. godine u NZJZ-u PGŽ-a pretraženo je 1050 uzoraka na prisustvo specifičnih IgM i IgG protutijela od kojih je 358 (34,1\%) imalo pozitivna IgM protutijela na $B$. burgdorferi $u$ testu ELFA, potvrđena WB testom (slika 3). U 2019. godini su specifična IgM protutijela ELFA testom detektirana i potvrđena WB-om u 207 (26,1\%) od 793 uzorka (slika 4). Porast broja pozitivnih uzoraka uočen je u razdoblju od svibnja do rujna. U 2018. godini najveći je broj uzoraka s pozitivnim IgM protutijelima bio u lipnju (71 ili 19,83\%), a 2019. godine u srpnju (38 ili 18,35 \%). Najmanji broj pozitivnih uzoraka u objema promatranim godinama zabilježen je u siječnju i prosincu.

Raščlamba zemljopisne raspodjele serodijagnostički potvrđenih slučajeva lajmske borelioze pokazuje da je njihov najveći broj u 2018. godini zabilježen na području grada Rijeke, zatim Opatije, Viškova i Matulja (slika 5). Nijedan slučaj nije utvrđen na području otoka Krka, Cresa, Malog Lošinja te području Jelenja, Mošćeničke Drage, Vinodola i Mrkoplja. U 2019. godini ponovno je najveći broj pozitivnih nalaza zabilježen iz uzoraka s područja Rijeke, Opatije, Lovrana, Viškova i Matulja.

U razdoblju od 2009. do 2019. godine HZJZ-u je prema podatcima iz HZSLJ-a u RH prijavljeno 510 $\pm 115,71$ oboljelih godišnje ${ }^{8}$. U 2019. godini broj 

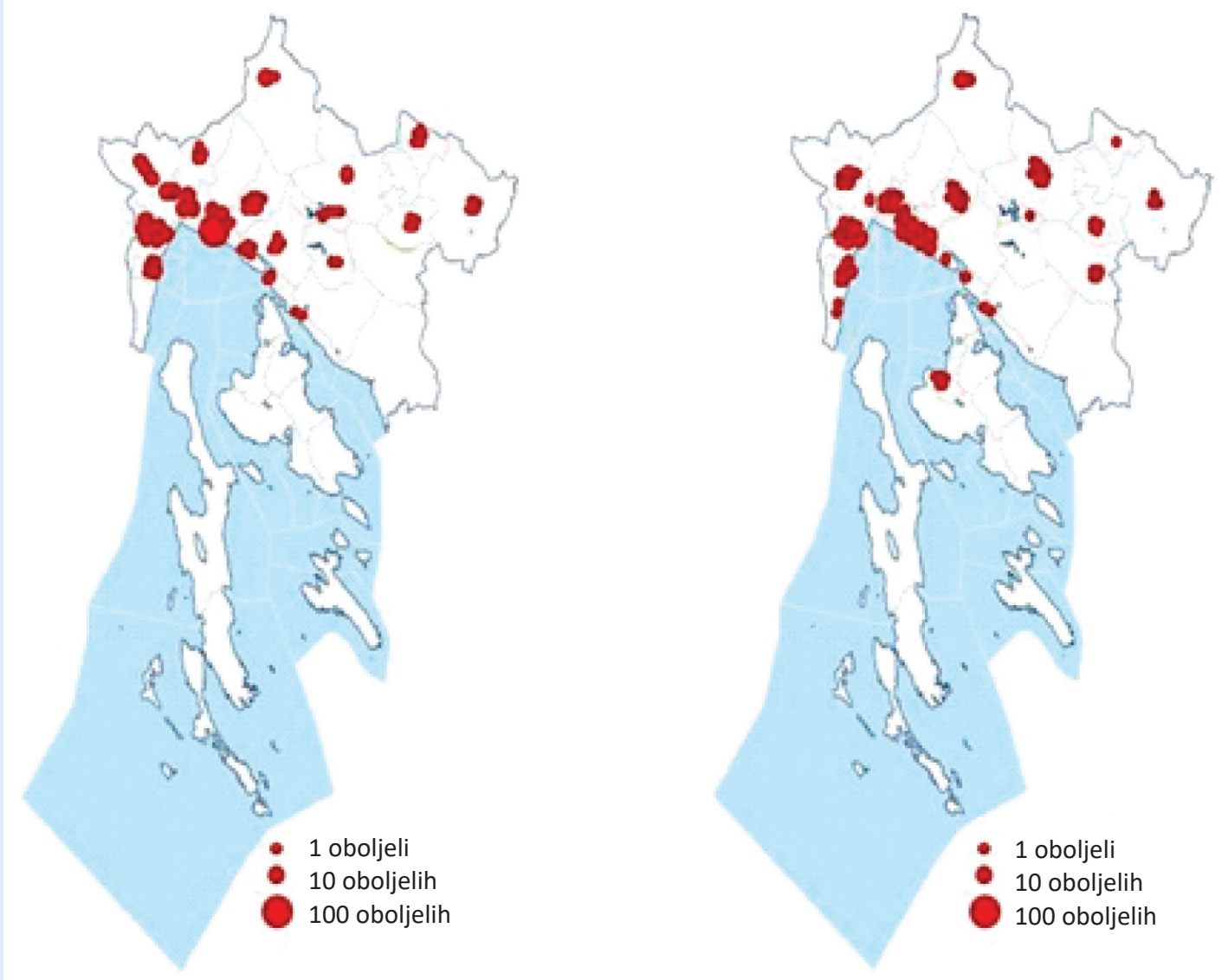

Slika 5. Zemljopisna rasprostranjenost serodijagnostički potvrđenih slučajeva lajmske borelioze u Primorsko-goranskoj županiji tijekom 2018. i 2019. godine

prijavljenih slučajeva u PGŽ-u iznosio je 42,3 \% od ukupnog broja slučajeva prijavljenih u RH.

\section{RASPRAVA}

Pojava borelioze povezana je s rasprostranjenošću krpelja iz roda Ixodes u području između 33. i 65. stupnja zemljopisne širine umjerenog klimatskog pojasa sjeverne hemisfere ${ }^{4}$. Za razvoj krpelja osobito su pogodni bjelogorični šumski predjeli s visokim travama i grmljem na vlažnoj zemlji prekrivenoj listincem, s obzirom na to da je krpeljima potrebna stalna relativna vlažnost od $80 \%$ i više. Optimalna je temperatura za razvoj $B$. burgdorferi između 33 i $37{ }^{\circ} \mathrm{C}$. Rasprostranjenost krpelja i njihova aktivnost znatno ovisi o klimatskim promjenama9 ${ }^{9}$ Krpelji između svakog od triju razvojnih stadija trebaju krvni obrok. Prijenos borelija zbiva se preko sline za vrijeme hranjenja krpelja na životinjskom domaćinu ili čovjeku. Najznačajnije za transmisiju borelija jesu nimfe koje se hra- ne u vrijeme proljeća i ranog ljeta ${ }^{4,9}$. Zbog ovakve biološke aktivnosti krpelja lajmska borelioza ima sezonski karakter, odnosno pojavljuje se od ranog proljeća do kasne jeseni, s najvećim brojem oboljelih u kasno proljeće i rano ljeto što su pokazali i naši rezultati i rezultati drugih autora iz $\mathrm{RH}^{3,4,9}$. Opadanje broja oboljelih započinje u srpnju i kolovozu zbog porasta temperature i pada vlažnosti zraka. Stopa infekcije krpelja u Europi kreće se od $12 \%$ u sjevernoj Europi, $14 \%$ u zapadnoj Europi do $23 \%$ u južnoj, odnosno $24 \%$ u istočnoj Europi, što za Europu daje prosječnu stopu infekcije od $13,7 \%$. Veću stopu infekcije pokazuju adulti $(18,6 \%)$ u odnosu na nimfe $(10,1 \%)$. Razlikuju se regije s niskom stopom infekcije (nimfe $\leq 11 \%$; adulti $\leq 20 \%$ ), regije $s$ visokom stopom infekcije (nimfe > $11 \%$; adulti > $20 \%$ ) i regije s ekstremno visokom stopom infekcije krpelja $(>30 \%)^{2}$. Rijpkema i sur. pretraživali su populaciju krpelja u endemskim područjima sjeverne Hrvatske i odre- 
dili stopu infekcije od $45 \%$, pri čemu su detektirali sve tri patogene vrste borelija ${ }^{10}$. Broj prijava oboljenja od lajmske borelioze na razini cijele $\mathrm{Hr}$ vatske dostupan je iz podataka dostavljenih HZJZ$u^{8}$. Iz njih je vidljivo da je prijavljeno prosječno $510 \pm 115,71$ oboljelih godišnje u razdoblju od 2009. do 2019. godine. Najveći broj oboljelih 2018. godine vjerojatno je uzrokovan većim brojem testiranja oboljelih i češćim boravkom u prirodi uz neodgovarajuću primjenu preventivnih mjera za zaštitu od ugriza krpelja. Najmanji broj oboljelih zabilježen je 2017. godine i iznosi 429 . Uočljivo je da u 2019. godini broj prijavljenih slučajeva u PGŽ-u iznosi čak 42,3 \% od ukupnog broja slučajeva prijavljenih u RH. Razlozi mogu biti klimatološke karakteristike promatranog razdoblja, povećano prijavljivanje i odlazak oboljelih na pregled i liječenje. Naime, prema podatcima Državnog hidrometeorološkog zavoda za 2019. godinu na području PGŽ-a već je u veljači postalo ekstremno toplo s normalnom ili vrlo visokom vlažnošću zraka, što izrazito pogoduje umnožavanju krpelja i povećanom boravku ljudi u njihovom prirodnom okolišu ${ }^{11}$. Porast broja oboljelih uočljiv je kada se uspoređuju rezultati analize broja prijava lajmske borelioze u RH koju su proveli Mulić i sur., a odnosi se na razdoblje od 1999. do 2008. godine. Ovi su autori zabilježili prosječno 290 oboljelih na godinu, što je u odnosu na desetogodišnje razdoblje koje smo mi promatrali znatno manji broj prijava oboljelih ${ }^{3}$. Autori koji su analizirali zemljopisnu rasprostranjenost lajmske borelioze u RH utvrdili su najveću pojavnost bolesti u u središnjoj i sjevernoj Hrvatskoj te PGŽ-u' ${ }^{2,3,4,9}$. Endemična su područja Hrvatsko zagorje, područje oko Koprivnice, Čakovca te područje uz Zagrebačku goru ${ }^{4}$. Linija razgraničenja između županija s višom i onih s niskom incidencijom prostire se duž $45^{\circ}$ sjeverne geografske širine. Utvrđena je statistički izrazito značajna razlika u incidenciji bolesti između sjevernog i južnog dijela Hrvatske karakterizirana visokom incidencijom na sjeveru $(14,5)$ i niskom na jugu $(0,7)$ te omjerom incidencije od $1: 21,6$ na jugu u odnosu na sjever ${ }^{9}$. Sličan trend pada broja oboljelih u južnim područjima zabilježen je i u drugim europskim zemljama, poput Italije, Španjolske i Grčke. Ropac i sur. odredili su prosječnu godišnju incidenciju lajmske boreli- oze u RH od 11,7 u periodu od 2012. do 2016. godine. Zabilježili su znatno višu incidenciju od čak 19,3 u najranijoj životnoj dobi od 0 do 9 godina ${ }^{9}$. $\mathrm{U}$ RH je incidencija lajmske bolesti slična Finskoj $(12,7)$ i Španjolskoj $(9,8)$, no znatno je niža u odnosu na Sloveniju (155) i Austriju (500) ${ }^{4,9}$.

Promatranjem zemljopisne distribucije serološki potvrđenih pozitivnih uzoraka krvnog seruma zapazili smo veću pojavnost pozitivnih uzoraka pacijenata $s$ područja grada Rijeke i gradova Liburnije u odnosu na Gorski kotar, Vinodol i otoke u Kvarnerskom zaljevu. To je u skladu s ranijim istraživanjem seroprevalencije metodom indirektne imunofluorescencije u Gorskom kotaru koja je 2000. godine pokazala nizak postotak seropozitivnosti (IgG protutijela) šumskih radnika $(4,7 \%)$ i općeg stanovništva (3\%). Međutim, ista studija je u odnosu na naše istraživanje pokazala nisku razinu seropozitiviteta kod stanovništva primorskog područja $(2,7 \%)^{13}$. Područje Gorskog kotara je uz kontinentalnu Hrvatsku endemsko žarište za krpeljni meningoencefalitis pa bi bilo za očekivati da je veća stopa infekcije i za lajmsku boreliozu. Međutim, stalni boravak u endemskom kraju vjerojatno je uzrok većeg broja asimptomatskih infekcija te veće prokuženosti tamošnjeg stanovništva. Protutijela na $B$. burgdorferi nalaze se ne samo u oboljelog nego i u zdravoj populaciji zbog prisutnosti borelija u okolišu ${ }^{4}$.

Svega polovina oboljelih seropozitivna je u primarnom stadiju infekcije, dok u kasnijim stadijima seropozitivnost raste na 90-100\%. Često su pacijenti sa svježim eritemom seronegativni, pa se dijagnoza postavlja na temelju kliničke slike i epidemioloških podataka o kretanju u prirodi i pronalasku krpelja na koži. Kod bolesnika koji imaju neurološke simptome neophodno je dokazati specifična protutijela u serumu i likvoru, ${ }^{5,6}$. Osjetljivost ELISA i WB testova vrlo je heterogena i kreće se oko $50 \%$ kod erythema migrans, $77 \%$ kod neuroborelioze, $97 \%$ kod acrodermatitis chronica atrophicans i $73 \%$ kod nespecifične kliničke slike lajmske borelioze ${ }^{6}$. Protutijela su specifična za genotip i njihova prisutnost u serumu nije znak otpornosti na ponovnu infekciju ${ }^{4}$.

Prema smjernicama HZJZ-a postupanje kod uboda krpelja je jednostavno. Krpelja je potrebno ukloniti što prije zato što je rizik od infekcije veći 
što je krpelj duže pričvršćen. Vjerojatno je potrebno od 24 do 36 sati da dođe do transmisije borelija sa zaraženog krpelja ${ }^{5,9}$. Potrebno je oprati ruke i pincetu prebrisati antiseptikom. Krpelja odmah izvaditi zahvaćajući ga pincetom što bliže glavici te ga laganim povlačenjem izvući iz kože. Kožu zatim prebrisati antiseptikom. Tako dugo dok se ne proizvede adekvatno cjepivo, jedino nam preostaje temeljit samopregled i pravilno uklanjanje vektora unutar 24 sata, kao najvažnija metoda prevencije bolesti.

\section{ZAKLJUČAK}

Naše je istraživanje potvrdilo zapažanja drugih autora iz Hrvatske o visokoj pojavnosti lajmske borelioze u PGŽ-u te o sezonalnosti od kasnog proljeća do rane jeseni u vrijeme najveće aktivnosti krpelja zbog njihovog složenog životnog ciklusa i većeg boravka stanovništva u prirodi tijekom ljetnih mjeseci. Posljednjih godina, sve veći broj oboljelih bilježi se u zimskim mjesecima jer sve blaže zime pogoduju većoj aktivnosti krpelja. Krpeljima je potrebna visoka relativna vlažnost, zbog čega najbolje opstaju u bjelogoričnim šumama s vlažnom zemljom i grmljem, a PGŽ nudi takve uvijete. Kako bismo spriječili ugrize krpelja, a time i širenje lajmske borelioze, od izuzetne je važnosti pridržavati se preporuka za zaštitu od ugriza krpelja koje je izdao HZJZ te povećati svjesnost ljudi na svim područjima RH o ovoj emergentnoj zoonozi.

Izjava o sukobu interesa: Autori izjavljuju kako ne postoji sukob interesa.

\section{LITERATURA}

1. Kalenić S, Vraneš J. Spirohete. In: Kalenić S (ed). Medicinska mikrobiologija. Zagreb: Medicinska naklada, 2019; 276-278.

2. Rauter C, Hartung T. Prevalence of Borrelia burgdorferi sensu lato genospecies in Ixodes ricinus ticks in Europe: a metaanalysis. Appl Environ Microbiol 2005;71:7203-7216.

3. Mulić $R$, Petković $B$, Klišmanić $Z$, Jerončić I. Bolesti koje se prenose krpeljima na području Hrvatske. Liječ Vjesn 2011;133:89-95.

4. Maretić T. Erythema Migrans. Medicus 2008;17:71-83.

5. Maretić T. Borrelia species. In: Begovac J, Božinović D, Lisić M, Barišić B, Schoenwald S (eds). Infektologija. Zagreb: Profil, 2006;655-662.

6. Leeflang MM, Ang CW, Berkhout J, Bijlmer HA, Bortel W Van, Brandenburg AH et al. The diagnostic accuracy of serological tests for Lyme borreliosis in Europe: a systematic review and meta-analysis. BMC Infect Dis 2016;16:140.

7. Krpelji i bolesti koje najčešće prenose u Hrvatskoj te preventivne mjere zaštite od krpelja [Internet]. Zagreb: Hrvatski zavod za javno zdravstvo. Inc. c2016 [cited 2021 Jan 7]. Available from: https://www.hzjz.hr/sluzba-epidemiologija-zarazne-bolesti/krpelji-i-bolesti-koje-najcesce-prenose-u-hrvatskoj-te-preventivne-mjere-zastite-od-krpelja/.

8. Stevanović R, Capak K, Benjak T. Zarazne bolesti, cijepljenje i mikrobiološka dijagnostika. In: Stevanović $R$, Capak K, Benjak T (eds). Hrvatski zdravstveno-statistički ljetopis za 2019 godinu. Zagreb: Hrvatski zavod za javno zdravstvo, 2020;174-177.

9. Ropac D, Šokman B, Stašević I, Kurečić Filipović S. Epidemiološke osobitosti lajmske bolesti u Republici $\mathrm{Hr}$ vatskoj u razdoblju od 2012. do 2016. godine. Acta Med Croatica 2019;73:151-7.

10. Rijpkema S, Golubić D, Molkenboer M, Verbeek-De Kruif $\mathrm{N}$, Schellekens J. Identification of four genomic groups of Borrelia burgdorferi sensu lato in Ixodes ricinus ticks collected in a Lyme borreliosis endemic region of northern Croatia. Experimental \& Applied Acarology 1996;20:2330.

11. Ocjena mjeseca, sezone, godine; Praćenje klime [Internet]. Zagreb: Državni hidrometeorološki zavod. Inc. c2019 [cited 2021 Apr 26]. Available from: https://mete o.h r/klima.php? section $=\mathrm{klima}$ pracenje\&param=ocjena\&el=msg_ocjena\&MjesecSezon $\mathrm{a}=4$ \&Godina $=2019$.

12. Mulić $R$, Antonijević $S$, Klišmanić $Z$, Ropac $D$, Lučev $O$. Epidemiological Characteristics and Clinical Manifestations of Lyme Borreliosis in Croatia. Military Medicine 2006;171:1105-9.

13. Poljak I, Troselj-Vukić B, Miletić B, Morović M, RuzićSabljić E, Vucemilović A et al. Low sero-prevalence of Lyme borreliosis in the forested mountainous area of Gorski Kotar, Croatia. Croat Med J 2000;41:433-6. 